\title{
The Academic Profession in Canada: Perceptions of Canadian University Faculty about Research and Teaching
}

Bryan Gopaul

University of Rochester

Glen A. Jones

Ontario Institute for Studies in Education, University of Toronto

Julian Weinrib

University of Toronto

Amy Metcalfe

University of British Columbia

Donald Fisher

University of British Columbia

Yves Gingras

Université du Québec

Kjell Rubenson

University of British Columbia

\begin{abstract}
Previous scholarly attention to the experiences of faculty members has emphasized the contexts of US institutions, with minimal attention to the experiences of faculty members at Canadian universities. This paper presents the findings of the Canadian component of an international survey that was administered in 19 different jurisdictions to understand the perceptions of faculty members
\end{abstract}


about the nature and scope of changes to academic work. As such, the paper explores the perceptions on research and teaching of full-time faculty members affiliated with Canadian universities. Overall, faculty members revealed that Canadian universities have strong, engaging, and vibrant research and teaching environments, yet there are also areas for improvement. Specifically, findings showed that faculty members perceived considerable autonomy with respect to research activities, despite the increasing need to secure external funding for research. Also, faculty expressed substantial commitment to teaching undergraduate students but a lack of clarity about some issues related to graduate teaching. The survey results provide an important baseline for future studies of Canadian universities and the working conditions of the professoriate in a time of rapid institutional and professional change.

\section{Résumé}

Jusqu'à présent, les études scientifiques sur l'expérience du corps professoral ont surtout porté sur le contexte étatsunien, accordant très peu d'attention à l'expérience vécue dans les universités canadiennes. Cet article présente les résultats de la partie canadienne d'un sondage international effectué dans 19 juridictions, et dontlebutétait de comprendrela perception du corps professoral envers la nature et la portée de changements modifiant le travail académique. Dans l'ensemble, les membres du corps professoral ont confié que le milieu de la recherche et de l'enseignement est solide, stimulant et dynamique, bien que des points restent à améliorer. Plus précisément, notre recherche révèle que les membres du corps professoral perçoivent une autonomie considérable sur le plan des activités de recherche, malgré le besoin grandissant d'obtenir du financement externe pour la recherche. De plus, les membres du corps professoral ont exprimé leur engagement capital envers l'enseignement au premier cycle, mais aussi un manque de clarté quant à certains problèmes liés à l'enseignement aux cycles supérieurs. Dans un contexte de changements institutionnels et professionnels rapides, les résultats du sondage fournissent un important point de départ pour de futures études sur les universités canadiennes et les conditions de travail du corps professoral.

\section{Introduction}

There has been an increasing interest in studying the experiences of university professors over the last two decades (Acker, 2003; Austin, 1992; Finklestein, 2010; Schuster \& Finklestein, 2006). The demands of public trustees and policy-makers for greater transparency, particularly in terms of understanding how members of the academic profession spend their time, have provided a rationale for a range of studies on academic work (O’Meara, Terosky, \& Neumann, 2008). Studies have explored, for example, faculty reward systems and tenure processes (Braskamp \& Ory, 1994; Tierney \& Rhoades, 1994), the importance of broadening the definition of scholarship (Boyer, 1990; O'Meara \& Rice, 2005), and recruitment and socialization processes (Wulff \& Austin, 2004) as well as the teaching and research loads and the general work organization of professors (Bertrand, 1991, 1993; Bertrand, Foucher, Jacob, Fabri, \& Beaulieu, 1994). 
While there has been a concerted and sustained scholarly interest in studying the professoriate in the United States and other countries with mature higher education systems, there has been relatively little research on the experiences of faculty members at Canadian institutions of higher education. A number of Canadian researchers have explored matters of inequity across faculty members at Canadian universities, such as issues of gender (Acker, 2003; Acker \& Armenti, 2004; CAUT, 2010; Expert Panel on Women in University Research, 2012) and the concomitant rise in part-time, contingent academic workers (Field, Jones, Karram Stephenson, \& Khoyetsyan, 2014; Muzzin, 2009; Rajagopal, 2002). However, these studies further reinforce the need for additional research to comprehensively examine the experiences of faculty members in Canadian universities. This paper is part of a body of scholarship exploring the experiences of full-time members at Canadian universities by drawing on the results of the 2007-2008 Changing Academic Profession (CAP) survey. Previous work related to this project includes studies of the remuneration of Canadian university faculty members (Jones \& Weinrib, 2012); perceptions of early career academics (Jones et al., 2012); perceptions of faculty related to university governance and management (Metcalfe et al., 2011); gender differences in academic productivity (Metcalfe \& Padilla-Gonzáles, 2013); the evolving balance between teaching and research in Canadian universities (Jones et al., 2014); and faculty job satisfaction (Weinrib et al., 2013). Our objective in this paper is to present and analyze data from the CAP project regarding the perceptions of Canadian university faculty on research and teaching in Canadian universities. For this particular paper, we provide a snapshot of data that relate to perceptions of teaching and research. Prior to examining the CAP survey in greater detail, we review relevant research on the academic profession in Canada as well as comment on the Canadian higher education "system."

\section{The Canadian Context}

Unlike the state-driven policy contexts of many of the countries participating in the CAP project, the higher education policy landscape in Canada is highly decentralized, as the provinces and territories govern the educational systems within their respective jurisdictions. Under the Canadian constitutional arrangement, the 10 provinces and three territories have legislative authority for all public policy relating to the organization and delivery of formal educational services within their jurisdictions, including higher education. There is no national ministry or binding policy lever for higher education. Universities function under provincial legislation, and most were created as autonomous notfor-profit corporations that receive public support through provincial operating grants. There is considerable variation in the funding arrangements and governance structures for higher education in each province and territory (Shanahan \& Jones, 2007).

Despite this variation, Canadian universities on the whole comprise a mature higher education sector with a global reputation for high quality and internationally leading levels of post-secondary educational attainment (OECD, 2012). There has been, however, surprisingly little research conducted on key segments of Canada's university sector. This paper will engage with one such under-examined area: the nature and scope of the academic work performed by full-time faculty members at Canadian universities.

Four trends that directly impact academic work in Canadian universities, especially in the context of research and teaching, have been the rise of accountability frameworks 
and managerial regimes (Slaughter \& Rhoades, 2004), the prominence of faculty unionization (Dobbie \& Robinson, 2008), increased debate over the expected division of teaching and research by full-time faculty, with correlating debates over institutional differentiation within the sector (Clark, Trick, \& Van Loon, 2011), and the commercial influence over research activity through targeted funding initiatives (Fisher, Atkinson-Grosjean \& House, 2001; Metcalfe, 2010). With regards to the first of these trends, national circumstances influence how accountability and managerialism frameworks impact universities within individual jurisdictions, and the Canadian context has experienced many of the most prominent global trends in this regard, including conflicting definitions of "relevant" research, increased reliance on and competition for targeted research funding, and the encroaching ubiquity of entrepreneurial strategies amongst faculty members (Chan \& Fisher, 2008; Enders \& Musselin, 2008; Olssen \& Peters, 2005). These factors, amongst others, have intensified the milieu of academic work, since in some systems "faculty are subject to unfair tenure systems, work expectations, mission creep, managerial reform, chilly climates, and a lack of support and mentoring" (O’Meara et al., 2008, p. 16). This intensification has been particularly influential on the nature and scope of research and teaching activities of both full- and part-time faculty members at universities across the globe. In this paper, we discuss these dynamics as they pertain to full-time faculty members at Canadian universities.

The second trend that has influenced the work of academics in Canadian universities is the powerful role of unionization in the higher education sector. The degree of unionization has significant implications for the level of faculty salaries and benefits, as well as working conditions and policies around tenure and promotion. Instability in the higher education sector in the 1970 s led to a broad movement towards faculty unionization in Canadian universities, and within a decade "the landscape was transformed" as unionization had encompassed over $50 \%$ of university professors across the country (Tudiver, 1999, p. 85). The trend continued in the 1990 s and 2000s, and the vast majority of university faculty are now members of recognized bargaining units. Importantly, other categories of university instructors, including graduate students and non-tenure-track positions, have also unionized at many institutions, frequently in separate union bodies from full-time faculty (Field et al., 2014; Jones, 2013). These alternative groupings focus on similar issues to those of their full-time counterparts, especially with regards to salaries, benefits, and job security. The high level of unionization in the Canadian university sector is an important contextual feature of the environment and determines the structure within which academic work is conceptualized, performed, and evaluated (Gravestock, 2011; Jones et al., 2014).

The third trend highlights the increasing debate about the separation of teaching and research and subsequent focus on institutional differentiation. This trend has been driven in many provinces by fiscal necessity; the traditional university model in Canada, whereby a near totality of university faculty members focus on both research and teaching, is increasingly viewed as a legacy of a bygone era marked by economic growth and predictable budgets. The massification of higher education in Canada, marked by world-leading attainment levels (OECD, 2012), coupled with the significant cost of running universities using a comprehensive teacher-scholar model as the standard, has created significant tensions for provincial governments in an era of fiscal uncertainty and crisis. Reforms 
in British Columbia led to the creation of new, teaching-intensive universities, while two former Alberta colleges have evolved into universities with a strong emphasis on teaching. In Ontario, teaching-focused universities have been suggested as a possible remedy for the current situation (Clark et al., 2011), while some rectors in Québec have pushed for the creation of two types of universities (Gingras, 2013). This debate is partially informed by disagreements over the added value that research fosters amongst teaching faculty but mostly is guided by the argument that the current model of university education is no longer sustainable and that teaching and research should increasingly be considered as separate streams for university faculty.

Finally, the trend of increased pressure to conduct research in areas targeted by the federal government of Canada has impacted the work of Canadian university faculty members. This process has been particularly salient in areas perceived as having high levels of commercial viability and is a response to historically low levels of industry-academia collaboration in the Canadian university sector (Industry Canada, 2007; OECD, 2011). Canadian universities have long been considered woefully inadequate at fostering innovation and development opportunities in partnership with industry, primarily driven by the high level of state involvement in the economic utilization of scientific research (AtkinsonGrosjean, House, \& Fisher, 2001; Rasmussen, 2008; Slaughter \& Leslie, 1997). Since the early 2000s, the federal government has responded to this reality and the ascension of knowledge-based economic discourse in the global marketplace by establishing a number of federal research programs focused on the commercialization of university research and the establishment of university-industry relations, such as an array of Networks of Centres of Excellence, as well as industrial training and development programs targeting post-secondary students (Industry Canada, 2007).

Several of these programs have elicited sharp critiques from the academic community with regards to perceived underfunding and marginalization of specific disciplines viewed as having less commercial viability. Many of these critiques contend that the federal government is using arms-length means to undermine academic autonomy by incentivizing full-time faculty to focus more on research than on teaching, and on particular types of research rather than the full range of academic inquiry (Atkinson-Grosjean et al., 2001; Metcalfe \& Fenwick, 2009; Ozaga, 2007; Polster, 2007). Given the rise of these four prominent trends, we turn now to a discussion of the CAP study that helps to frame how higher education institutions and faculty members are responding to these mounting pressures to research and to teaching.

\section{The Changing Academic Profession Study}

To understand how recent changes in the funding, governance, and administration of higher education systems and institutions were impacting post-secondary faculty members, an international project was initiated in 2006 in order to examine the nature and extent of these changes as experienced internationally. The result of this initiative was the CAP project, which ultimately involved the administration of a common survey questionnaire to a representative sample of faculty in 19 jurisdictions (18 countries plus Hong Kong). The CAP survey represents one of the most comprehensive attempts to obtain national and comparative data on the perceptions of faculty members concerning the nature of their work and their academic work environment. The survey questionnaire was influ- 
enced by the First International Survey of the Academic Profession, which was conducted in 1992 by the Carnegie Foundation for the Advancement of Teaching (Altbach, 1996). Canada was not included in the 1992 survey and so it is impossible to analyze change over time, but the Canadian administration of the CAP survey remains one of the largest, most comprehensive studies of the Canadian professoriate conducted to date.

In the Canadian context, the CAP project provides unique quantitative data on the work, experiences, and backgrounds of full-time tenured and tenure-track faculty members at Canadian universities. The Canadian component of the study was designed to gather responses from a representative sample of full-time faculty members at Canadian universities. A two-stage cluster sample was created at two distinct levels: the institution and the individual. The popular taxonomy for institutional type amongst Canadian universities uses the following three categories: Medical/Doctoral, Comprehensive, and Primarily Undergraduate. A random sample was generated with this institutional taxonomy and consisted of 18 institutions: four Medical/Doctoral, six Comprehensive, and eight Primarily Undergraduate. At least one university in each of Canada's 10 provinces was represented in this study, and for each university, only full-time faculty members were surveyed. ${ }^{1}$ Other academic individuals with titles of Instructor, Lecturer, Research Associate, and Clinical Faculty were not included in the Canadian CAP survey. Also, faculty members with administrative titles, such as Dean and Vice President, were excluded from the survey.

At the end of October 2007, 6,693 potential participants were sent an invitation via email with a hyperlink to a web-based survey, which was then closed in mid-December, 2007. Another attempt to secure respondents was initiated in April 2008, and the survey was finally closed in May 2008, having obtained 1,152 valid returns for a response rate of $17.21 \%$. Details on the survey sampling framework and response rates are provided in Table 1.

Table 1.

Canadian CAP Survey Sampling Framework

\begin{tabular}{|c|c|c|c|c|c|c|c|c|c|c|c|c|}
\hline \multirow[b]{3}{*}{ University Type } & \multicolumn{4}{|c|}{ Gross Sample* } & \multicolumn{4}{|c|}{ Net Sample } & \multicolumn{4}{|c|}{ Returned Sample } \\
\hline & \multicolumn{2}{|c|}{ Institutions } & \multicolumn{2}{|c|}{ Faculty } & \multicolumn{2}{|c|}{ Institutions } & \multicolumn{2}{|c|}{ Faculty } & \multicolumn{2}{|c|}{ Institutions } & \multicolumn{2}{|c|}{ Faculty } \\
\hline & $(\#)$ & $(\%)$ & $(\#)$ & $(\%)$ & $(\#)$ & $(\%)$ & $(\#)$ & $(\%)$ & $(\#)$ & $(\%)$ & $(\#)$ & (\%) \\
\hline Medical Doctoral & 15 & 31.9 & 18840 & 59.7 & 4 & 22.2 & 2245 & 33.5 & 4 & 22.2 & 442 & 38.4 \\
\hline Comprehensive & 11 & 23.4 & 7806 & $24 \cdot 7$ & 6 & $33 \cdot 3$ & 3109 & 46.5 & 6 & $33 \cdot 3$ & 501 & 43.5 \\
\hline \multirow[t]{2}{*}{ Undergraduate } & 21 & $44 \cdot 7$ & 4908 & 15.6 & 8 & $44 \cdot 4$ & 1339 & 20.0 & 8 & $44 \cdot 4$ & 209 & 18.1 \\
\hline & 47 & 100.0 & 31,554 & 100.0 & 18 & 100.0 & 6,693 & 100.0 & 18 & 100.0 & 1,152 & 100.0 \\
\hline
\end{tabular}

*Source: CAUT Almanac, 2008

In addition to surveying multiple university types in Canada, the demographic data closely resemble the characteristics of full-time university faculty across Canada, as can be seen in Table 2. Further, the CAP survey sample closely mirrors the disciplinary distribution of faculty in Canada (Table 3). 
Table 2.

Demographics of Full-Time Canadian University Faculty

\begin{tabular}{|c|c|c|c|c|c|c|c|c|c|}
\hline \multirow[b]{3}{*}{ Characteristics } & \multicolumn{4}{|c|}{ Faculty in Canada, 2005-2006* } & \multirow{2}{*}{$\begin{array}{l}\mathrm{CDN} \\
\mathrm{CAP}\end{array}$} & \multirow{2}{*}{$\begin{array}{l}\mathrm{CDN} \\
\mathrm{CAP}\end{array}$} & \multirow{2}{*}{$\begin{array}{l}\text { CDN } \\
\text { CAP }\end{array}$} & \multirow{2}{*}{$\begin{array}{l}\text { CDN } \\
\text { CAP }\end{array}$} & \multirow{2}{*}{$\begin{array}{l}\mathrm{CDN} \\
\mathrm{CAP}\end{array}$} \\
\hline & & & & & & & & & \\
\hline & $(\%)$ & $(\%)$ & $(\%)$ & $(\%)$ & $(\%)$ & $(\%)$ & $(\%)$ & $(\%)$ & $(\%)$ \\
\hline Male & 67.3 & & & & 59.1 & & & & \\
\hline Female & 32.7 & & & & 40.9 & & & & \\
\hline White & & 84.2 & & & & 85.0 & & & \\
\hline Visible minority & & 15.8 & & & & $15 \cdot 0$ & & & \\
\hline Canadian citizen at birth & & & 59.0 & & & & 68.1 & & \\
\hline Canadian citizen (2007) & & & 86.8 & & & & & 89.5 & \\
\hline Assistant professor & & & & 28.0 & & & & & 28.7 \\
\hline Associate professor & & & & 32.0 & & & & & $35 \cdot 3$ \\
\hline Full professor & & & & 34.0 & & & & & 36.0 \\
\hline Other teaching title & & & & 6.0 & & & & & 0.0 \\
\hline & 100.0 & 100.0 & & 100.0 & 100.0 & 100.0 & & & 100.0 \\
\hline $\mathrm{N}=$ & 38,298 & 38,298 & 38,298 & 38,298 & 982 & 1,008 & 955 & 797 & 1,152 \\
\hline
\end{tabular}

*Source: CAUT Almanac, 2008

Table 3.

Canadian University Faculty by Discipline

\begin{tabular}{lrlr}
\hline Canada* $\left.^{*} \mathrm{~N}=38,298\right)$ & $(\%)$ & Canadian CAP $(\mathrm{N}=1,092)$ & $(\%)$ \\
\hline Education & 7.0 & Teacher training and education science & 7.9 \\
Fine and applied arts & 4.0 & & \\
Humanities and related & 15.0 & Humanities and arts & 15.7 \\
& & $\begin{array}{l}\text { Social and behavioural sciences } \\
\text { Susiness and administration, economics }\end{array}$ & 15.9 \\
Social sciences and related & 27.0 & Law & 2.5 \\
Agricultural and biological sciences & & Agriculture & 1.0 \\
(excluding health professions) & 7.0 & Life sciences & 5.7 \\
Engineering and applied sciences & 9.0 & Engineering, manufacturing, \\
& & construction, and architecture & 7.1 \\
Health professions/occupations & 16.0 & $\begin{array}{l}\text { Medical sciences, health-related } \\
\text { sciences, social services }\end{array}$ & 14.6 \\
Mathematics, physical sciences & 13.0 & Physical sciences, mathematics, \\
& & computer sciences & 13.4 \\
Not reported & 1.0 & Other/not applicable & 6.5 \\
& 99.0 & & 100.1 \\
\hline
\end{tabular}

*Source: CAUT Almanac, 2008 
In this paper, we focus on the responses to questions related to faculty perceptions of research and teaching. We begin by reviewing findings on the research activities of faculty, following by perceptions of teaching, and then look at faculty perceptions of their balance of interests and work between research and teaching.

\section{Research at Canadian Universities}

This section presents the findings of select CAP survey questions in order to provide a more comprehensive understanding of faculty perceptions regarding an array of researchrelated issues, such as researcher autonomy, work patterns, professional interests, and preferred means and media of publication. All of this is done to paint a more holistic picture of how full-time faculty at Canadian universities are currently experiencing the role of research within their working lives.

\section{Research-Related Work at Canadian Universities}

The first general theme for analysis is conceptualized as research productivity, dissemination, and collaboration, and it relates to the amount, type, and nature of research conducted by the surveyed faculty members. More specifically, we ask what are the collaborative dynamics and what are the chosen media for dissemination of research-related results for faculty members at Canadian universities? The CAP survey contained a number of questions that directly addressed these issues.

In addition to the preferred media that Canadian academics use to disseminate research, faculty were asked: "How many of the following scholarly contributions have you completed in the past three years?" Eleven categories were put forward, ranging in scope from scholarly books authored to artistic works performed. Table 4 presents the responses from Canadian faculty on their use of forms of dissemination and on their level of productivity.

Table 4 .

Percentage of Faculty Reporting Use of Forms of Dissemination, and the Level of Productivity Reported by Those Who Use Each Form

\begin{tabular}{lcc}
\hline Form of Research Dissemination & $\begin{array}{c}\text { \# of Publications } \\
\text { (mean/3 years) }\end{array}$ & \% of Respondents \\
\hline Paper presented at a scholarly conference & 8.1 & 93 \\
Article published in academic book/journal & 6.2 & 89 \\
Report/monograph for a funded project & 1.4 & 44 \\
Professional article for a newspaper/magazine & 1.4 & 41 \\
Other & 0.6 & 10 \\
Scholarly books authored or co-authored & 0.3 & 25 \\
Scholarly books edited or co-edited & 0.3 & 19 \\
Artistic work performed or exhibited & 0.3 & 5 \\
Patent secured on a process or invention & 0.1 & 5 \\
Computer program written for public use & 0.1 & 6 \\
Video or film produced & 0.1 & 4 \\
\hline
\end{tabular}


In terms of the professional dynamics involved in the publication of the above research, a number of CAP questions investigated the form, structure, and processes associated with faculty responses. The collaborative dimension of academic research was highlighted by a number of direct questions, with the following findings. A large percentage of respondents (84\%) indicated that they had collaborated during the year prior to the survey being conducted (2007) with other researchers in one or more of their research projects, 68\% reported having collaborated with persons at other institutions within Canada, and $63 \%$ reported having collaborated with international colleagues. In terms of co-authorships stemming from collaborate research activities, $40.3 \%$ of respondents indicated that they had co-authored with colleagues in Canadian institutions, while only $12.7 \%$ reported that they had co-authored with colleagues in foreign countries. Despite the low level of co-authorship with foreign scholars, however, $31 \%$ of Canadian respondents indicated that they had published in a foreign publication during the previous year.

When the data were compared to bibliometric studies for the year 2007, there appeared to be a high level of variance in the reported levels of collaboration with international colleagues. In 2007, nearly $45 \%$ of all Canadian academic publications were the result of international collaborations (Lebel \& Lemelin, 2009). This of course varies according to disciplines, the humanities being the less collaborative (as measured by co-authored papers) and the sciences reporting as the most collaborative, with the social sciences falling in between. Interprovincial collaborations are usually less frequent than international co-authorships. Small provinces collaborate more with other provinces, and larger ones, such as Québec and Ontario, collaborate less with the rest of Canada, with only 15-17\% of their papers being co-authored with colleagues from other provinces (Larivière, Gingras, \& Archambault, 2006; Lebel \& Lemelin, 2009).

\section{Conceptualizing Research}

Questions relating to the second theme that emerged from the CAP survey are grouped under the heading conceptualizing research. They focus on how individual academics relate to the purported goals and expectations of research vis-à-vis the dissemination and use of their research. As issues of accountability and managerialism continue to influence public spending on research, the measurement and evaluation of research outputs-as well as the politics surrounding such practices-remain defining components of the $21^{\text {st }}$ century academic professional, with tangible implications for debates around academic freedom. In light of this dynamic, faculty perceptions regarding desirable or preferable uses of their research, as well as the perceived role of non-academic influences over the research process and the dissemination of findings, are central themes of this study's analysis. The following section will take up these issues by examining pertinent CAP survey questions in order to portray a broad aggregate of full-time academics' perceptions at Canadian universities, acknowledging that nuances exist at sub-aggregate levels that will be well served by further analysis in subsequent studies.

The first grouping of questions relate to the perceived goals and expectations that faculty have regarding their research, including broader considerations of the purpose of research within the $2 \mathbf{1}^{\text {st }}$-century university. The findings indicate that a majority of fulltime faculty members conceptualize research and knowledge production as fundamentally intertwined with broader societal issues. For instance, $68 \%$ strongly agreed or agreed 
that "scholarship includes the application of academic knowledge in real-life settings," and $59 \%$ of respondents strongly agreed or agreed that "faculty in my discipline have a professional obligation to apply their knowledge to problems in society." The manner in which this knowledge is transmitted, however, presents more uncertain results. Seventysix percent of respondents strongly agreed or agreed that "scholarship is best defined as the preparation and presentation of findings on original research," 61\% strongly agreed or agreed that "high expectations of useful results and application are a threat to the quality of research," and a correlate question regarding the quantity of research indicated similar concerns, as $72 \%$ of respondents strongly agreed or agreed that "high expectations to increase research productivity are a threat to the quality of research." These responses seem to indicate that there is trepidation amongst Canadian academics regarding the influence that societal issues should have on determining the nature, scope, and application of research in Canadian universities. While a majority of respondents acknowledged that "real-life settings" can benefit from academic research, the survey results did not support the expectation of application as being the driving force of research.

The second grouping of questions relating to the conceptualization of research builds on the latter conclusion and questions the influence that external and non-academic actors have on the construction, funding, and evaluation of research activities and practices within Canadian universities, particularly in relation to the quality, quantity, and scope of research. In general, the CAP responses indicate that the academic profession in $\mathrm{Ca}-$ nadian universities is operating within a tension between internal and external priorities. Some responses highlight the increased influence that funding sources and external actors play in the determination and evaluation of research, but these findings are in tension with the relatively strong perception of autonomy within the academic workforce, including perceptions of strong support coming from institutional administrators with regard to academic freedom and research activities.

In terms of external influence, specifically around issues of funding, the following CAP findings are most pertinent: $75 \%$ of respondents strongly agreed or agreed that "the pressure to raise external research funds has increased since my first appointment," $45 \%$ of respondents indicated that external sponsors or clients have influence over the research activities of individual faculty members, and only $21 \%$ of respondents reported that the level of institutional research funding is excellent or very good. Further to this last finding, participants indicated that $73.3 \%$ of research funding is from non-institutional or external sources. These responses indicate that external or non-academic actors are perceived as playing a significant role in the defining and funding of research in Canadian universities. Furthermore, institutional resources are perceived as being inadequate to meet the research demands of Canadian academics. As will be examined below, these findings are, however, balanced by a wide array of responses that indicate high levels of autonomy are still held by academics in relation to the setting of academic standards, the evaluation of research, and the motivating factors of research activities in Canadian universities.

In terms of decisions regarding the setting of internal research priorities at Canadian universities, only $2 \%$ of respondents indicated that government or external actors were the primary influence, with individual faculty (35\%), institutional managers (27\%), academic unit managers (19\%), and faculty committees/boards (17\%) fulfilling the role of arbiters for institutional research priorities. A similar question focused on the actors with primary 
decision-making influence for the evaluation of research activities, with the following results: faculty committee/boards (38\%), academic unit managers (21\%), individual faculty members (20\%), institutional managers (13\%), and government or external stakeholders (8\%). The strong role that academics and institutional actors play in setting the priorities and rubrics of research evaluation is supported by the responses to two related questions: only $11 \%$ of respondents strongly agreed or agreed with the statement "Restrictions on the publication of results from my publicly funded research have increased since my first appointment," and $61 \%$ of respondents strongly agreed or agreed that "the administration supports academic freedom." While there appeared to be a funnelling of resources by external sources, the vast majority of academics remained resistant to the idea that "research funding should be concentrated (targeted) on the most productive researchers," with only $21 \%$ of respondents strongly agreeing or agreeing with this statement.

Taken on the whole, the above findings show that while institutions are perceived by Canadian academics as being incapable of meeting research funding demands-which is resulting in, or perhaps a result of, external actors influencing the dominant funding mechanisms available to academic staff-respondents generally indicated that universities and their administrative and professional units remain the primary arbiters of research priorities, research evaluation and professional support. Consequently, it appears that the increased influence of external actors through research funding mechanisms has not resulted in a perception of increased restrictions or targeting of research activities at Canadian universities. One possible hypothesis that may explain these circumstances is that the extremely strong legacy of institutional and sub-institutional autonomy in $\mathrm{Ca}-$ nadian universities (for example, see Jones, 2002) represents a substantial negotiating layer for the institutionalization of external influences and conditionalities that may be attached to external funding.

\section{Commercial Influence Over Research}

A final theme of analysis that reflects significant trends in the broader literature on academic work in the $21^{\text {st }}$ century relates to the role of private-sector influence and commercial-related research in publicly funded universities. Any examination of the role that external actors are playing in Canadian universities should consider the growth of public-private partnership funding schemes initiated in Canada over the last 10 years, such as the Canadian Foundation for Innovation (CFI) and the Networks for Centres of Excellence (NCE) (Atkinson-Grosjean et al., 2001; CFI, 2008; Metcalfe, 2012; Metcalfe \& Fenwick, 2009; Polster, 2007; Tudiver, 1999; Shanahan \& Jones, 2007), and the general growth of market-oriented activities or incentivized funding schemes in public higher education institutions around the world (Fisher, Atkinson-Grosjean, \& House, 2001; Fisher \& Rubenson, 2010; Marginson, 2006, 2007; Musselin, 2005; Olssen \& Peters, 2005; Slaughter \& Leslie, 1997; Slaughter \& Rhoades, 2004). A number of CAP survey questions directly engage with issues of private or commercial influence over university-based research activities. The findings of these questions indicate that Canadian academics as a whole appear to be predominantly disengaged from the private sector and are resistant to commercially oriented research activities, despite the cautionary tales raised by researchers of both the Canadian and the global academic profession. 
In terms of funding sources, respondents indicated that in the aggregate, only $4.5 \%$ of their total research funding is derived from business or industry sources, with an additional $3.7 \%$ coming from other sources that may or may not represent private-sector investment or partnership. In terms of research emphasis, for the question, "How would you characterize the emphasis of your primary research this (or the previous) academic year?" responses averaged 4.2 on a 5-point Likert scale for the "commercially oriented/ intended for technology transfer" category, with 1 representing "very much" and 5 representing "not at all." Lastly, only $40 \%$ of respondents indicated that their "institution emphasizes commercially oriented or applied research." One question engaged with the issue of academic freedom and privately funded research by asking whether "restrictions on the publication of results from my privately funded research have increased since my first appointment," with only $11 \%$ of faculty indicating that they strongly agreed or agreed with the statement.

The above findings and responses appear to indicate that the private sector and commercial interests do not play a significant role in the determination of research priorities or activities for most tenured faculty members in Canadian universities. This is consistent with Statistics Canada's aggregate data on university R\&D by source of funding, which indicate that about $18 \%$ comes from the private sector (for-profit as well as non-profit). More importantly, the large majority of these private-sector investments are concentrated in the biomedical and engineering sciences, so the majority of professors are not touched by the presence of privately funded research in academia, which has been relatively stable over the last 10 years (Statistics Canada, 2013). While individual faculty members perceive institutions as being relatively interested in promoting commercially oriented or applied research, for the most part this interest has not translated into substantial shifts in research practices or interests at the individual level.

\section{Teaching in Canadian Universities}

The perceptions of teaching expressed by faculty members at Canadian universities through the CAP survey reveal a robust and dedicated team of individuals who are committed to student learning, passionate about engaging students in the classroom, and interested in improving students' learning experiences. The discussion that follows addresses these perceptions of teaching as framed by undergraduate education and graduate education, respectively.

In the context of teaching, a major theme was the emphasis on undergraduate teaching and perceptions related to the academic preparedness of undergraduate students. During the academic year, faculty members spend nearly 20 hours per week preparing and conducting teaching or teaching-related activities, which eclipses all other academic tasks. Of the time spent on teaching, faculty members spend $63.1 \%$ focusing on undergraduate teaching. Faculty members reported that the average number of undergraduates per course was 59 students. For instructional methods in the classroom, the survey explored the use of group work, computer-assisted learning, and distance education, and while faculty members did use these aforementioned methods, lecturing was the overwhelmingly preferred method of instruction. Also, these faculty members were heavily invested in developing course materials. This commitment to teaching is fostered by institutional cultures that support both the assessment and the improvement of teaching. Specifically, 55\% 
of respondents strongly agreed or agreed that they are encouraged to improve their teaching in response to teaching evaluations, and, importantly, $58 \%$ of individuals revealed that their institutions provide adequate training courses for teaching improvement. While the CAP survey questions regarding teaching evaluations were intended to describe the extent of administrative oversight and support for the improvement of the quality of teaching, faculty do not necessarily perceive the university's role as that of a neutral player, given the high stakes of performance evaluation for the purposes of tenure and promotion, in the case of tenure-track faculty. Despite the absence or presence of institutional supports for the improvement of the quality of teaching, faculty may be resistant to perceived interferences by university administration in the faculty-student relationship and peer-to-peer collegiality, as reported in Canadian studies conducted by Iqbal $(2013,2014)$.

This focus on teaching permeates interactions with students. Most faculty members spend time interacting with undergraduate students outside of the classroom, through face-to-face interactions in office hours and via email communications. Specifically, 95\% of respondents interact with students outside of the classroom and 96\% engage in email communication with students. Interestingly, there was a strong sense from faculty members that students were not equipped with basic skills prior to enrolling in a course/institution, which results in faculty members believing that they have to spend more time teaching basic skills due to student deficiencies. So, $55 \%$ of respondents strongly agreed or agreed that they spend more time than they would like on basic skills, while $77 \%$ of individuals strongly agreed or agreed that they inform students about issues of plagiarism and cheating. While the nature of these deficiencies was not delineated in the CAP survey, the strong sense of obligation by faculty members in Canada to inform students about issues related to plagiarism and cheating in their courses suggests that particular expectations and norms related to study skills, evaluations, and academic writing operate at these institutions (and in academe more broadly), of which some students may not be aware. The CAP results also support Canadian studies on academic integrity that suggest a shifting locus of responsibility between students, faculty, and institutions when it comes to education about such guidelines (Gallant \& Drinan, 2008; Griffith, 2013).

A second theme that emerged, although with considerably less frequency than the first theme, was that of teaching and graduate education. From an organizational perspective, faculty members experience institutional targets related to the number of hours in the classroom and to the number of students per class for undergraduate student populations. For instance, $80 \%$ and $56 \%$ of respondents indicated that their institutions set quantitative load targets for hours in the classroom and number of students in the class, respectively. This sort of institutional transparency works to stabilize undergraduate education where faculty members are aware of explicit norms and expectations from their respective institutions. The context of graduate education is a little different, in that faculty members do not experience similar direction through institutional targets related to the number of graduate students supervised, as only $18 \%$ of faculty members revealed that their institutions had load targets or regulatory mechanisms for the supervision of graduate students.

On average, Canadian faculty members spend only $9.8 \%$ of their time instructing doctoral students, and doctoral student class sizes are small (five students per course). These faculty members spend more of their time teaching in master's programs than in doctoral programs, and the number of students in master's classes is much larger than in doctoral 
programs. For instance, the amount of total instruction time in master's courses is larger than in doctoral courses, at $\mathbf{2 1 . 1 \%}$, and the class size for master's courses nearly doubles that of doctoral courses, at 9.8 students per course. So, faculty members experience important nuances to their teaching experiences in the contexts of undergraduate and graduate levels of education, as well as through teasing out the master's and doctoral programs related to graduate education. These nuances are related to institutional priorities of transparency with respect to each sub-set of education as well as broader institutional, regional, and national interests of undergraduate and graduate education.

\section{Relationships Between Research and Teaching}

An important entry point into assessing the intersections of the components of academic work emerges from responses to the question "Please indicate your views on the following: (answer scale $1=$ strongly agree to $5=$ strongly disagree). $\ldots$. Your research activities reinforce your teaching" and "Your service activities reinforce your teaching." Interestingly, $82 \%$ of faculty members agreed or strongly agreed that research reinforces teaching, while only $43 \%$ agreed or strongly agreed that service reinforces teaching. Up to this point, our discussion has focused on the separation of research and teaching: an examination into how each operates distinctly and separately from the other as components of academic work. A further question in the CAP survey explored the relationship between research and teaching by asking, "Regarding your own preferences, do your interests lie primarily in teaching or in research?" Respondents heavily favoured an investment in both teaching and research, as reported by $80 \%$ of respondents; however, importantly, $54 \%$ of total respondents indicated that their interests lay in both teaching and research but leaned toward research, while $26 \%$ said they were interested in both teaching and research but favoured teaching. This finding is not surprising, given professional and institutional emphasis on research activity, including the practice of awarding grants based, in part, on the applicants' excellence in achieving sustained and robust research trajectories. As Canadian universities become more driven by external resources, even internal allocation of funding is more competitive, potentially affecting the perceptions and behaviours of the Canadian professoriate with regard to the relative stature of research activities (Polster, 2012). Yet, the dominance of research activity over time spent teaching and advising students cannot be fully explained by resource dependency, as teaching is also a revenue stream for Canadian universities, particularly with the increasing emphasis on the recruitment of international students, who pay higher fees (Beck, 2012). Indeed, the research/teaching binary is possibly a manifestation of academic culture that requires further investigation, as suggested by Macfarlane (2015).

The distribution of workloads across the academic year and the segregation of work by "teaching terms" and "non-teaching terms" may contribute to the existence of, or reinforce the perception of, the binary between teaching and research. One way of assessing how faculty members spend their time across the different aspects of academic work is through a question on workload: "Considering all your professional work, how many hours do you spend in a typical week on each of the following activities?" This question was posed for when classes are in session and when they are not. For when classes are in session, Canadian respondents reported spending an average of 16 hours per week 
on research and research-related activities (reading literature, writing, conducting experiments, doing fieldwork), compared to 19.6 hours on teaching-related activities, 4.3 hours on service, 7.9 hours on administrative work, and 2.7 on other academic activities, for a total of 50.7 hours per week. When classes are not in session, the reported average amount of time spent on research rose dramatically to 28.5 hours per week, with a corresponding drop to 5.4 hours of teaching. Respondents indicated that they spent four hours on service, 6.8 hours on administration, and three hours on other academic work during non-teaching terms, for a total of 47.7 hours per week.

Although the nature and scope of how research may inform teaching were not addressed by the CAP survey, findings from other questions on teaching may suggest possible interpretations. For instance, $60 \%$ of faculty members indicated that they use international content or perspectives in their teaching. This broadening of curricula may reflect an increased globalized research environment with more collaborative projects across researchers and institutions, wherein the findings or implications of such research can be applied to multiple jurisdictions.

\section{Summary and Conclusion}

Although the CAP survey was designed by an international research team for an international context, in this paper we have analyzed the Canadian survey data in relation to four key trends in higher education in this country: the rise of accountability frameworks, an increase in academic unionization, an increasing differentiation at the professional and institutional levels with respect to teaching and research activities, and the potential effects of targeted research funding on the broad academic endeavour. The CAP survey results indicate that Canadian academics are generally satisfied with the levels of autonomy in the context of their professional research endeavours and responsibilities, but there is a strong recognition that external pressures and the expectation of commercial or applied forms of knowledge are threatening autonomous research. While the CAP responses indicate that full-time academics are aware of the rising tension between external actors and institutional or professional expectations, the majority believe that their research interests have not been negatively influenced by such patterns of influence and that institutional administrators continue to support basic academic freedoms. Furthermore, despite the recognition by the majority of Canadian faculty that academic research can be beneficial to broader societal issues, a similar majority indicated that these societal issues should not be the driving force of academic research and that expectations of higher productivity levels threaten overall academic quality. When taken as a whole, these responses appear to support the idea that academics are best served by selfregulation and that, to this point, self-regulation has for the most part been maintained by the current configuration of power in Canadian higher education institutions. So, while pressures of accountability and targeted research funding may be operating to some extent, participant responses indicated relative comfort and autonomy within the current arrangements for research activity.

While one can hypothesize as to the reason for this continued resistance to management by non-academic forces, specifically looking at the strong tradition of institutional autonomy in the Canadian context, further study is required in order to understand how this autonomy has been maintained in Canada while having been sacrificed in part or in 
whole in other jurisdictions, particularly the other Anglophone countries, as exemplified in Slaughter and Leslie's account of academic capitalism in Canada, the United States, the UK, and Australia (Slaughter \& Leslie, 1997). Further, recent scholarship (Metcalfe, 2010) suggests that trends of academic capitalism are more prevalent in Canada than previously articulated, and evidence of commercialization and its mechanisms encourages further research to explore how academic autonomy may be shifting (Grant \& Drakich, 2010). In addition, the CAP responses require further examination along a number of trajectories, particularly in terms of different institutional types (research-focused vs. teaching-focused), disciplines, professional ranks, and gender. For instance, previous research from the Canadian CAP survey indicated only modest differences in job satisfaction, workload, and other working conditions between junior professors and their more senior peers (Jones et al., 2012), but it would be interesting to look at differences in responses by university type, STEM fields versus liberal arts, etcetera.

In terms of working patterns, the CAP results indicate that Canadian full-time academics work far longer than the traditional notions of full-time work-wherein individuals might work 35-44 hours per work week-both when classes are in session and when they are not, and this is particularly salient in terms of the time spent on research, with faculty reporting an average 16 hours a week during teachings session and 28.5 during non-teaching terms, compared to 19.6 hours of teaching when classes are in session and only 5.4 hours per week when classes are not in session. As outlined in the section on research, this commitment is echoed in the high level of productivity and dissemination practices, particularly through conference presentations and article publications. Given that the overall level of satisfaction for Canadian academics is quite high (Weinrib et al., 2013), there is no reason to believe that these numbers are viewed as problematic; however, the CAP survey questionnaire offered limited opportunities to analyze the relationship between particular work patterns and overall satisfaction levels.

The teaching experiences of faculty members at Canadian universities suggest that faculty members are highly invested in their teaching and in their students' learning, through large commitments of time and energy in developing course materials, using various instructional techniques, and communicating with students in office hours and through email. Part of this commitment may come from general job satisfaction in the nature of their academic work; however, faculty members may be partly committed to issues of teaching and learning due to the perceived need to spend more time than anticipated on teaching basic skills to students. While institutional clarity through explicit regulatory mechanisms and load targets facilitates stability in undergraduate education, the context of graduate education is much different for these faculty members. For most faculty, the time spent teaching doctoral courses is minimal and doctoral class sizes are small. Since just over half of respondents communicated that their institutions provide adequate training for teaching improvements, there is a need to examine possible institutional differences related to this commitment to improvement. Hence, an exploration of how different institutions commit resources, time, and policies to teaching improvement would be a fruitful area of future investigation.

Importantly, faculty members articulated a strong belief that their research reinforces their teaching; hence, the interactions between the different components of academic life, and the degree to which professors have a holistic orientation to their work, is an impor- 
tant area for future research. As Canada has been described as a "balanced system" with regard to the missions of teaching and research (Shin, Arimoto, Cummings, \& Teichler, 2014; Teichler, Arimoto, \& Cummings, 2013), further comparison with other balanced systems, such as those in the US, UK, and Australia, may be worthwhile, particularly as the audit culture and regulatory mechanisms of these national systems are quite different from those in the Canadian context.

In addition to future research contributions, the findings from this research can inform particular policies and institutional practices. The focus of research productivity and autonomy in a context of increasing accountability and targeted funding suggests an imperative for explicit and co-ordinated efforts within departments and school units to ensure the sustainability of autonomy in research activity. Further, continued attention upon the tremendous commitments to teaching and to student support might be enacted differently at different institutions, across disciplines, and within school units. Specific institutional policy attention could emphasize more clarity regarding teaching strategies at the graduate level, as well as concentrated institutional commitments to continuous pedagogical improvement throughout an academic career.

As mentioned above, the forces of accountability and managerialism have been very active in trying to shape institutional research agendas and priorities. The data from the CAP survey in Canada, however, revealed important nuances to these seemingly "global" trends. Faculty unionization may be playing an important role in protecting faculty from external pressures and managerial practices. Many faculty respondents to the CAP study also noted that university administrators strongly support academic freedom, and this support may limit the adoption of certain types of managerial and accountability practices in Canada compared with in some other jurisdictions. Indeed, it may be that the relative autonomy of Canadian universities and individual faculty, when compared to international peer institutions and colleagues, has benefited the Canadian higher education sector.

The CAP study provides important findings on the perceptions of Canadian university faculty regarding research and teaching. These findings suggest that Canadian faculty work hard, and that most maintain a balance between teaching and research activities. Faculty devote considerable attention to undergraduate education, and they believe that their research activities contribute to their teaching. While they are clearly aware of, and concerned by, the potential pressures associated with directed research funding and commercialization, most believe that they still have high levels of freedom to determine their own programs of research.

\section{Note}

1. A detailed description of the design and method of the international CAP surveys can be found in earlier publications (see Locke \& Tiechler, 2007).

\section{References}

Acker, S. (2003). The concerns of Canadian women academics: Will faculty shortages make things better or worse? McGill Journal of Education, 38(3), 391-405.

Acker, S., \& Armenti, C. (2004). Sleepless in academia. Gender and Education, 16(1), 3-24. 
Altbach, P. G. (Ed.). (1996). The international academic profession. Portraits of fourteen countries. Princeton, NJ: Carnegie Foundation for the Advancement of Teaching.

Atkinson-Grosjean, J., House, D., \& Fisher, D. (2001). Canadian science policy and public research organizations in the $20^{\text {th }}$ century. Science Studies, 14 (1), 3-25.

Austin, A.E. (1992). Supporting junior faculty through a teaching fellows program. New Directions for Teaching and Learning, 1992(50), 73-86.

Beck,K.(2012).Globalization/s: Reproductionandresistanceintheinternationalization of higher education. Canadian Journal of Education/Revue canadienne de l'éducation, 35(3), 133-148.

Bertrand, D. (1991). Le travail professoral démystifié. Montréal, QC: Presses of the University of Québec.

Bertrand, D. (1993). Le travail professoral reconstruit. Au-delà de la modulation. Montréal, Canada: Presses of the University of Québec.

Bertrand, D., Foucher, R., Jacob., R., Fabri, B., \& Beaulieu, P. (1994). Le travail professoral remesuré. Unité et diversité. Montréal, QC: Presses of the University of Québec.

Boyer, E. 1990. Scholarship reconsidered. Princeton, NJ: Carnegie Foundation for the Advancement of Teaching.

Braskamp, L.A. and Ory, J.C. (1994). Assessing Faculty Work: Enhancing Individual and Institutional Performance. San Francisco, CA: Jossey-Bass.

Canada Foundation for Innovation [CFI]. (2008). 2007-2008 annual report. Ottawa, ON: Foundation for Innovation.

Canadian Association of University Teachers [CAUT]. (2010). The changing academy? A portrait of Canada's university teachers. CAUT Education Review, 12(1), 1-6.

Chan, A. S., \& Fisher, D. (Eds.). (2008). The exchange university: Corporatization of academic culture. Vancouver, BC: UBC Press.

Clark, I., Trick, D., \& Van Loon, R. (2011). Academic reform: Policy options for improving the quality and cost-effectiveness of undergraduate education in Ontario. Kingston, ON: McGill-Queen's University Press.

Dobbie, D., \& Robinson, I. (2008). Reorganizing higher education in the United States and Canada: The erosion of tenure and the unionization of contingent faculty. Labour Studies Journal, 33(1), 117-140.

Enders, J., \& Musselin, C. (2008). Back to the future? The academic professions in the $21^{\text {st }}$ century. In Higher Education to 2030. Volume 1: Demography (pp. 125-150). Paris: Centre for Educational Research and Innovation \& Organisation for Economic Cooperation and Development.

Expert Panel on Women in University Research. (2012). Strengthening Canada's research capacity: The gender dimension. Ottawa, ON: Council of Canadian Academies. 
Field, C. C., Jones, G. A., Karram Stephenson, G., \& Khoyetsyan, A. (2014). The "other" university teachers: Non-full-time instructors at Ontario universities. Toronto, ON: Higher Education Quality Council of Ontario.

Finkelstein, M. (2010). Diversification in the academic workforce: The case of the US and implications for Europe. European Review, 18(1), S141-S156.

Fisher, D., Atkinson-Grosjean, J., \& House, D. (2001). Changes in academic/industry/ state relations in Canada: The creation and development of the Networks of Centres of Excellence. Minerva: A Review of Science and Policy, 39, 299-325.

Fisher, D., \& Rubenson, K. (2010). Canada. In D. Dill \& F.A. Van Vught (Eds.), National Innovation and the Academic Research Enterprise: Public Policy in Global Perspective (pp. 62-116). Baltimore, MD: The Johns Hopkins University Press.

Gallant, T. B., \& Drinan, P. (2008). Toward a model of academic integrity institutionalization: Informing practice in postsecondary education. Canadian Journal of Higher Education, 38(2), 24-43.

Gingras, Y. (2013, 26 February). Les effets pervers d'une idée simpliste. Le Devoir, p. A6.

Grant, K. R., \& Drakich, J. (2010). The Canada Research Chairs program: The good, the bad, and the ugly. Higher Education, 59(1), 21-42.

Gravestock, P.(2011). Does teaching matter? The role of teaching in the tenure policies of Canadian universities (Doctoral dissertation). University of Toronto, Toronto, ON. Retrievedfromhttps://tspace.library.utoronto.ca/bitstream/1807/31764/6/Gravestock_ Pamela_S_201111_PhD_thesis.pdf

Griffith, J. (2013). Pedagogical or punitive?: The academic integrity websites of Ontario universities. Canadian Journal of Higher Education, 43(1), 1-22.

Industry Canada. (2007). Mobilizing science and technology to Canada's advantage. Ottawa, ON: Industry Canada.

Iqbal, I. A. (2013). Academics' resistance to summative peer review of teaching: Questionable rewards and the importance of student evaluations. Teaching in Higher Education, 18(5), 557-569.

Iqbal, I. A. (2014). Don't tell it like it is: Preserving collegiality in the summative peer review of teaching. Canadian Journal of Higher Education, 44(1), 108-124.

Jones, G. A. (2002). The structure of university governance in Canada: A policy network approach. In A. Amaral, G. A. Jones, \& B. Karseth (Eds.), Governing higher education: National perspectives on institutional governance (pp. 213-234). Dordrecht, The Netherlands: Kluwer Academic Publishers.

Jones, G. A. (2013). The horizontal and vertical fragmentation of academic work and the implications for academic governance and leadership. Asia Pacific Education Review, 14(1). 
Jones, G. A., Gopaul, B., Weinrib, J., Metcalfe, A. S., Fisher, D., Gingras, Y., \& Rubenson, K. (2014). Teaching, research and the Canadian professoriate. In A. Arimoto, W. K. Cummings, J. C. Shin, \& U. Teichler (Eds.), Teaching and research in contemporary higher education: Systems, activities and rewards (pp. 335-356). Dordrecht, The Netherlands: Springer.

Jones, G. A., \& Weinrib, J. (2012). The organization of academic work and the remuneration of faculty at Canadian universities. In P. Altbach, L. Reisberg, M. Yukevich, G. Androushchak, \& I. F. Pacheco (Eds.), Paying the professoriate: A global comparison of compensation and contracts (pp. 83-93). New York, NY: Routledge.

Jones, G. A., Weinrib, J., Metcalfe, A. S., Fisher, D., Rubenson, K., \& Snee, I. (2012). Academic work in Canada: The perceptions of early-career academics. Higher Education Quarterly, 66(2), 189-206.

Larivière, V., Gingras, Y., and Archambault, É. (2006). Canadian collaboration networks: A comparative analysis of the natural sciences, social sciences and the humanities. Scientometrics, 68(3), 519-533.

Lebel, J., \& Lemelin, P. (2009). Research in Canada: A collaborative affair. Retrieved from http://www.ost.uqam.ca/Portals/o/docs/note/ost_note22_e.pdf

Locke, W., \& Teichler, U. (Eds.). (2007). The changing conditions for academic work and careers in select countries. Kassel, Germany: International Centre for Higher Education Research.

Macfarlane, B. (2015). Dualisms in higher education: A critique of their influence and effect. Higher Education Quarterly, 69(1), 101-118.

Marginson, S. (2006). Putting "public" back into the public university. Thesis Eleven, 84(1), 44-59.

Marginson, S. (2007). University mission and identity for a post post-public era. Higher Education Research \& Development, 26(1), 117-131.

Metcalfe, A. (2010). Revisiting academic capitalism in Canada: No longer the exception. Journal of Higher Education, 81(4), 489-514.

Metcalfe, A., \& Fenwick, T. (2009). Knowledge for whose society?: Knowledge production, higher education, and federal policy in Canada. Higher Education, 57, 209225 .

Metcalfe, A. S. (2012). The changing culture of academic research: From organizations to networks. In B. Stensaker, J. Välimaa, \& C. S. Sarrico (Eds.), Managing reform in universities: The dynamics of culture, identity and organisational change (pp. 98-113). Basingstoke, UK: Palgrave.

Metcalfe, A. S., Fisher, D., Gingras, Y., Jones, G. A., Rubenson, K., \& Snee, I. (2011). Canada: Perspectives on governance and management. In W. Locke, W. K. Cummings, \& D. Fisher (Eds.), Governance and management in higher education: The perspectives of the academy (pp. 151-174). Dordrecht, The Netherlands: Springer. 
Metcalfe, A. S., \& Padilla-González, L. E. (2013). Underrepresentation of women in the academic profession: A comparative analysis of the North American region. NASPA Journal About Women in Higher Education, 6(1), 1-21.

Musselin, C. (2005). European academic labor markets in transition. Higher Education, 49(1/2), 135-154.

Muzzin, L. (2009, May). Equity, ethics, academic freedom and the employment of contingent academics. Academic Matters, 19-22.

Olssen, M., \& Peters, M. (2005). Neoliberalism, higher education, and the knowledge economy: From free market to knowledge capitalism. Journal of Educational Policy, $2 O(3), 313-345$.

O’Meara, K., \& Rice, R. E. (Eds.) (2005). Faculty priorities reconsidered: Encouraging multiple forms of scholarship. San Francisco, CA: Jossey-Bass

O’Meara, K., Terosky, A. L., \& Neumann, A. (2009). Faculty careers and work lives: A professional growth perspective (ASHE Higher Education Report, vol. 34, no. 3). San Francisco, CA: Jossey-Bass.

Organisation for Economic Co-operation and Development [OECD]. (2011). Main science and technology indicators, 2011/12. Retrieved from https://stats.oecd.org/Index. aspx?DataSetCode=MSTI_PUB

Organisation for Economic Co-operation and Development [OECD]. (2012).Education at a glance 2012: OECD indicators. Retrieved from http://www.oecd.org/edu/EAG\%20 2012_e-book_EN_200912.pdf

Ozaga, J. (2007). Knowledge and policy: Research and knowledge transfer. Critical Studies in Education, 48(1), 63-78.

Polster, C. (2007). The nature and implications of the growing importance of research grants to Canadian universities and academics. Higher Education, 53(5), 599-622.

Polster, C. (2012). Reconfiguring the academic dance: A critique of faculty's responses to administrative practices in Canadian universities. TOPIA: Canadian Journal of Cultural Studies, 1(28), 115-141.

Rajagopal, I. (2002). Hidden academics: Contract faculty in Canadian universities. Toronto, ON: University of Toronto Press.

Rasmussen, E. (2008). Government instruments to support the commercialization of university research: Lessons from Canada. Technovation, 28(8), 506-517.

Schuster, J., \& Finkelstein, M. (2006). The American faculty: The restructuring of academic work and careers. Baltimore, MD: The Johns Hopkins University Press.

Shanahan, T., \& Jones, G. A. (2007). Shifting roles and approaches: Government coordination of postsecondary education in Canada, 1995-2006. Higher Education Research \& Development, 26(1), 31-43.

Shin, J. C., Arimoto, A., Cummings, W. K., \& Teichler, U. (Eds.). (2014). Teaching and research in contemporary higher education. Dordrecht, The Netherlands: Springer. 
Simmons, N. (2009). Playing for SoTL impact: A personal reflection. International Journal for the Scholarship of Teaching and Learning, 3(2), 1-3.

Slaughter, S., \& Leslie, L. (1997). Academic capitalism: Politics, policies and the entrepreneurial university. Baltimore, MD: The Johns Hopkins University Press.

Slaughter, S., \& Rhoades, G. (2004). Academic capitalism and the new economy: Markets, state and higher education. Baltimore, MD: The Johns Hopkins University Press.

Statistics Canada. (2013). Table 358-ooo1-Gross domestic expenditures on research and development, by science type and by funder and performer sector, annual (dollars $x$ 1,OOO,OOo). Retrieved from http://www5.statcan.gc.ca/cansim/ a26?lang=eng\&id $=3580001$

Teichler, U., Arimoto, A., \& Cummings, W. K. (2013). Research and teaching: The changing views and activities of the academic profession. In U. Teichler, A. Arimoto, \& W. K. Cummings (Eds.), The changing academy: The changing academic profession in international and comparative perspectives, Volume 1 (pp. 117-163). Dordrecht, The Netherlands: Springer.

Tierney, W., \& Rhoades, G. (1994). Enhancing promotion, tenure and beyond: Faculty socialization as a cultural process. ASHE-ERIC Higher Education Report No. 6 (pp. 1-126). Washington, DC: The George Washington University Press.

Tudiver, N. (1999). Universities for sale: Resisting corporate control over Canadian higher education. Toronto, ON: Lorimer.

Warman, C., Woolley, F., \& Worsick, C. (2010). The evolution of male-female earnings differentials in Canadian universities, 1970-2001. Canadian Journal of Economics, 43(1), 347-472.

Weinrib, J., Jones, G., Metcalfe, A. S., Fisher, D., Gingras, Y., Rubenson, K., \& Snee, I. (2013). Canada: Canadian university academics' perceptions of job satisfaction - “...the future is not what it used to be.” In P. J. Bentley, H. Coates, I. R. Dobson, L. Goedegebuure, \& V. Lynn Meek (Eds.), Job satisfaction around the academic world (pp. 83-102). Dordrecht, The Netherlands: Springer.

Wulff, D., \& Austin, A. (Eds.). (2004). Paths to the professoriate: Strategies for enriching the preparation of future faculty. San Francisco, CA: Jossey-Bass.

\section{Contact Information}

Bryan Gopaul

Warner School of Education and Human Development

University of Rochester

bgopaul@warner.rochester.edu

Bryan Gopaul is an assistant professor of educational leadership in the Warner School of Education and Human Development, at the University of Rochester. His research focuses on doctoral education, the pipeline to the professoriate, and international higher education reform. 
Glen A. Jones is the Ontario Research Chair in Postsecondary Education Policy and Measurement and Interim Dean of the Ontario Institute for Studies in Education, at the University of Toronto. He is the author of more than 100 publications on higher education in Canada, including studies of university governance, systems, policy, and academic work. His most recent book (with Ian Austin) is Governance of Higher Education: Global Perspectives, Theories and Practice (Routledge, 2015). Information on his current projects can be found at www.glenjones.ca.

Julian Weinrib, $\mathrm{PhD}$, is a special projects officer in the Office of the Vice-President and Provost at the University of Toronto. His main research interests are post-secondary education system design, the academic profession, globalization of higher education, and the scholarship of teaching and learning.

Amy Metcalfe is an associate professor of Higher Education in the Department of Educational Studies at the University of British Columbia.

Donald Fisher is Acting-Principal of Green College and an emeritus professor in the Department of Educational Studies at the University of British Columbia. His research on philanthropy, university education, the social sciences, and academic-industry relations is supported by the Social Sciences and Humanities Research Council of Canada. Recent publications include a co-edited volume with William Locke and William K. Cummings, Changing Governance and Management in Higher Education: The Perspectives of the Academy (Dordrecht: Springer, 2011), and a co-edited volume with Kjell Rubenson, Theresa Shanahan, and Claude Trottier, The Development of Postsecondary Systems in Canada: A Comparison between British Columbia, Ontario and Quebec, 1980-2010 (McGill-Queen's University Press, 2014).

Yves Gingras is professor in the History Department and Canada Research Chair in the History and Sociology of Science at the Université du Québec à Montréal. His research focuses on the transformation of universities and the dynamic of scientific disciplines. His most recent books are Sociologie des sciences (Paris: Presses universitaires de France, 2012) and Les derives de l'évaluation de la recherche. Du bon usage de la bibliométrie (Paris: Raisons d'agir, 2013). He is also the editor of Controverses: accords et désaccords en sciences humaines et sociales (Paris: CNRS Éditions, 2014) .

Kjell Rubenson is an emeritus profesor at the University of British Columbia. His research deals with adult education and post-secondary education and the labour market. 